\title{
Little bluestem tiller defoliation patterns under continuous and rotational grazing
}

\author{
JUSTIN D. DERNER, ROBERT L. GILLEN, F. TED MCCOLLUM, AND KENNETH W. \\ TATE
}

Authors are former graduate research assistant, professor, Agronomy Department; professor, Animal Science Department; and former senior agriculturist, Agronomy Department, Oklahoma State University, Stillwater 74078.

\begin{abstract}
Defoliation patterns of little bluestem [Schizachyrium scoparium (Michx.) Nash] on tallgrass prairie were compared using continuous and rotational grazing systems on six 24-ha pastures for each system over a range of stocking rates $\left(0.28\right.$ to $\left.0.49 \mathrm{AU} \mathrm{ha}^{-1}\right)$ in 1991 and 1992. We tested the generalization that rotational grazing provides greater managerial control over the frequency, intensity, and uniformity of tiller defoliation compared to continuous grazing. Rotational system pastures were subdivided into 8 paddocks with 4 grazing cycles (3-7 day graze periods) per grazing season. Tillers were sampled biweekly in continuous system pastures and at the beginning, midpoint, and end of each grazing period in rotational system pastures. Multiple regression prediction equations were developed for grazed height, number of defoliation events in a grazing season, percent of tillers defoliated per sampling period (of continuous system) and grazing cycle (for rotation system), and number of defoliation events within a grazing cycle (rotational system). Grazed height decreased as stocking rate increased, but was not influenced by grazing system. The number of cumulative defoliation events per tiller increased with increasing stocking rate over the grazing season. Under similar stocking rates, a higher percentage of tillers were defoliated during the grazing season in the continuous than in the rotational grazing system. Within both grazing systems, percentage of tillers defoliated increased with increasing stocking rates. The percentage of tillers defoliated biweekly in continuous system pastures was similar over the grazing season; the percentage of tillers defoliated per cycle increased as grazing periods lengthened in rotational system pastures. A large number of tillers were defoliated during the second half of each grazing period. Less than $10 \%$ of tillers were regrazed within a grazing cycle, even at the highest stocking rate and longest grazing period. Rotational grazing provided greater managerial control over the frequency and uniformity of tiller defoliation; intensity of tiller defoliation was similar between the 2 grazing systems. We hypothesize higher range condition will be maintained over the long-term in rotational system pastures as little bluestem will remain more competitive and productive resulting from fewer defoliation events throughout the grazing season.
\end{abstract}

Key Words: defoliation frequency, grazed height, grazing system, range condition, Schizachyrium scoparium, stocking rate, tallgrass prairie

Little bluestem [Schizachyrium scoparium (Michx.) Nash], is one of the most important grasses in the tallgrass prairie and

\footnotetext{
Approved for publication by the Director, Oklahoma Agricultural Experiment Station. This research was supported under project H-2089. Authors wish to thank Brock Karges for facilitating livestock movement in rotational pastures and Dr. Larry Claypool for assistance in statistical analyses.

Manuscript accepted 26 Nov. 1993.
}

responds to defoliation as a decreaser (Brown and Stuth 1984). Yet, with many tillers per plant arranged in a caespitose growth form, little bluestem is often underutilized by livestock. Patch grazing results from a high frequency (number of defoliations/time period) and intensity (amount of plant material removed/defoliation) of defoliation of a small percentage of the tillers (Hinnant and Kothmann 1986).

A high frequency of tiller defoliation following the initial defoliation is assumed to be the predominant mechanism in producing patch grazing in continuous grazing systems. Unrestricted selective grazing of specific plant species throughout the grazing season often leads to overgrazing and an eventual reduction in population structure (Butler and Briske 1988) and productivity of the most palatable species (Kothmann 1980). Intervals between defoliations are affected by the rate of growth of defoliated tillers, the degree of selection for or against previously defoliated tillers, and seasonal changes in herbivore preference among species (Gammon and Roberts 1978c).

Grazing managers have begun to implement rotational grazing systems to increase the uniformity of species utilization and increase carrying capacity compared to continuous grazing systems. Rotational grazing provides an opportunity, through manipulation of the length of grazing period, to improve control of the frequency, intensity, and uniformity of defoliation (Denny and Barnes 1977, Hinnant and Kothmann 1986). However, Gammon and Roberts (1978a, 1978b) found heights of grazing, frequency of defoliation, and patterns of selection to be similar between rotational and continuous systems. Therefore, the proposed benefits of additional control over defoliation intensity and frequency in rotational grazing systems have not been conclusively demonstrated.

The specific objective of this study was to determine the effect of continuous and rotation grazing systems over a range of stocking rates on little bluestem tiller defoliation patterns in tallgrass prairie. Our primary emphasis was to test the generalization that rotational grazing provides greater managerial control over the frequency, intensity, and uniformity of defoliation compared to continuous grazing. Defoliation pattern studies involving rotational and continuous grazing systems on tallgrass prairie are limited (e.g., Gillen et al. 1990). Multiple regression prediction equations were developed for comparison of the tiller defoliation patterns between the 2 grazing systems. These prediction equations can be used as tools by land resource managers in assessing, developing, and implementing grazing management strategies.

\section{Study Area}

The study area is located on the Oklahoma State University Research Range about $21 \mathrm{~km}$ southwest of Stillwater, Okla. $\left(36^{\circ} 3^{\prime}\right.$ 
$\left.\mathrm{N} 97^{\circ} 14^{\prime} \mathrm{W}\right)$. The climate is continental with an average frost-free growing period of 204 days extending from April to October. Average precipitation at Stillwater is $831 \mathrm{~mm}$ with $65 \%$ falling as rain from May to October. Mean temperature is $15^{\circ} \mathrm{C}$ with average minimum and maximum temperatures ranging from $-4.3^{\circ} \mathrm{C}$ in January to $34^{\circ} \mathrm{C}$ in August (Myers 1982).

Major range sites found on the area are shallow prairie (33\%), loamy prairie $(25 \%)$, and eroded prairie $(22 \%)$. Sandy savannah dominates the remaining area. The shallow prairie sites have Grainola series soils (fine, mixed, thermic Vertic Haplustalf), which have a loam surface with silty clay subsoil. Coyle series soils (fine-loamy, siliceous, thermic Udic Argiustoll) comprise the loamy prairie sites. These soils have fine sandy loam surfaces with sandy clay loam subsoils. The eroded prairie sites are on old fields and have Renfrow (fine, mixed, thermic Udertic Paleustoll), Mulhall (fine-loamy, siliceous, thermic Udic Paleustoll), and Coyle series soils.

The study area vegetation is currently in a high seral state. Vegetation composition on a dry weight basis, determined by the dry weight rank method in August 1991, consisted of $28 \%$ little bluestem, 30\% other tallgrass [big bluestem (Andropogon gerardii Vitman), indiangrass [Sorghastrum nutans (L.) Nash], and switchgrass ( Panicum virgatum L.)], 25\% midgrasses, $13 \%$ forbs, and $4 \%$ shortgrasses and annual grasses.

\section{Methods}

Experimental treatments consisted of continuous and rotational grazing systems over a range of stocking rates $(0.28$ to $0.49 \mathrm{AU}$ $\mathrm{ha}^{-1}$ ). Stocking rate was not replicated within or between grazing systems. Each grazing system had six, 24-ha pastures. Rotational system pastures were subdivided into 8 paddocks. Within the rotational grazing system 4 grazing cycles were used. Graze periods were $3,4,5$, and 7 days for the first, second, third, and the fourth grazing cycle, respectively. Data were not taken from the first grazing cycle in 1991. Grazing by crossbred yearling cattle, with initial weights of $205 \mathrm{~kg} \mathrm{head}^{-1}(0.65 \mathrm{AU})$, began in late April and ended in late September (approximately 150 days).

Individual tillers of little bluestem were permanently marked with orange colored wire rings at the start of the grazing season in each pasture. Ten tillers were systematically located along three, $20-\mathrm{m}$ permanent transects at each of 3 locations $(100,200$, and 300 $\mathrm{m}$ from livestock water), for a total of 30 tillers at each location and 90 tillers per pasture. Data were pooled over the 3 locations.

Two paddocks, numbers 3 and 7 in the grazing sequence, were used as subsamples for each rotational system pasture. Paddocks grazed third in the grazing sequence in 1991 were grazed seventh in 1992 and vice versa. Data from the 2 paddocks were averaged over a grazing cycle.

Tillers in the continuous system pastures were sampled biweekly throughout the grazing season (total of 11 sample dates). Tillers in the rotational system pastures were sampled before, midpoint of (middle), and after (exit) each grazing period. Lost tillers (e.g., wire knocked off or tiller pulled up) were replaced with the nearest available tiller. Tiller measurements included the presence/absence of defoliation, total tiller height with leaves and extended, and the minimum height at which defoliation had occurred. Grazed edges of leaves and stems were marked with white latex paint to determine subsequent defoliation events. Means of grazed height were based on defoliated tillers. Only tillers not replaced during the grazing season were used in categorizing the number of defoliation events in a grazing season per tiller.

All data were analyzed using general linear model techniques for a completely randomized design with repeated measures. Grazing system and stocking rate were main factors, and year, sample date (continuous), grazing cycle (rotational), and observation within cycle (middle and exit, rotational) were repeated factors. Pastures were experimental units. Tiller means within pastures were used as observations for the analyses. Independent variables for the general linear models were quantitative and qualitative. Quantitative variables included stocking rate, stocking rate squared, and grazing cycle. Qualitative variables included grazing system, year, observation (rotational), and sample date (continuous). All possible interaction variables were included in the general linear models. Significant $(P<0.05)$ variables from the general linear models were used to develop multiple regression prediction equations. Prediction equations were developed for grazed height, number of defoliation events in a grazing season, percent of tillers defoliated per sampling period (for continuous system) and cycle (for rotational system), and number of defoliation events within a grazing cycle (for rotational system).

\section{Results and Discussion}

Precipitation for the water year (November-October) was $81 \%$ and $101 \%$ of average for 1991 and 1992, respectively. Growing season precipitation (May-August) was $92 \%$ of average for 1991 and $143 \%$ of average for 1992 . As a result of the above average growing season precipitation in 1992, forage production levels exceeded that of the previous year. September standing crop for the continuous system pastures was $2,890 \mathrm{~kg} \mathrm{ha}^{-1}$ in 1991 and 3,961 $\mathrm{kg} \mathrm{ha}^{-1}$ in 1992 . Values for the rotational system pastures were $3,437 \mathrm{~kg} \mathrm{ha}^{-1}$ in 1991 and $4,802 \mathrm{~kg} \mathrm{ha}^{-1}$ in 1992 . Utilization of little bluestem tillers declined in response to the increased forage production levels in 1992.

\section{Between Grazing Systems \\ Grazed Height}

Grazed height decreased as stocking rate increased (Fig. 1), but was not influenced by grazing system. Gammon and Roberts (1978a) also found grazed heights did not differ between continuous and rotational grazing on the Matopos Sandveld in Rhodesia. Although year was a significant variable in the prediction equation for grazed height, the effect of year may be biased due to the lack of data taken during the first grazing cycle from the rotational system

Table 1. Coemcients of multiple regression equations for defoliation events in a grazing season, D.E. = defoliation events, $Y R=$ year, $G R S Y=$ grazing system, $\mathrm{SR}=$ stocking rate, $\boldsymbol{R}^{2}=$ coefficient of determination. All regression coefficients significant at $\boldsymbol{P}<0.05$.

\begin{tabular}{|c|c|c|c|c|c|c|c|c|c|c|c|}
\hline D.E. & $b_{0}$ & YR & GRSY & SR & $\mathrm{SR}^{2}$ & $\begin{array}{c}\text { SR } \\
\text { *YR }\end{array}$ & $\begin{array}{l}\text { GRSY } \\
* \text { YR }\end{array}$ & $\begin{array}{l}\mathrm{SR}^{2} \\
\text { *YR }\end{array}$ & $\begin{array}{l}\text { SR*YR } \\
\text { *GRSY }\end{array}$ & $\begin{array}{l}R^{2 *} \text { YR } \\
{ }^{*} \text { GRSY }\end{array}$ & $R^{2}$ \\
\hline 0 & 41.1 & 42.3 & 10.7 & -89.4 & & -91.1 & & & & & 0.80 \\
\hline 1 & 40.0 & & 18.1 & -66.2 & & & -8.6 & & & & 0.70 \\
\hline 2 & 24.0 & -28.9 & & & & 64.1 & & & 2.4 & & 0.28 \\
\hline 3 & -4.8 & & & 58.9 & & & & & & & 0.32 \\
\hline 4 & -1.2 & & -7.8 & 41.0 & & & & & & & 0.48 \\
\hline 5 & -3.2 & & -7.1 & 34.5 & & & & & & & 0.56 \\
\hline 6 & 2.3 & & -5.8 & & 25.3 & & -16.4 & -11.3 & 94.4 & -110.6 & 0.36 \\
\hline$>6$ & 2.5 & & -4.6 & & 14.3 & & & & & & 0.42 \\
\hline
\end{tabular}




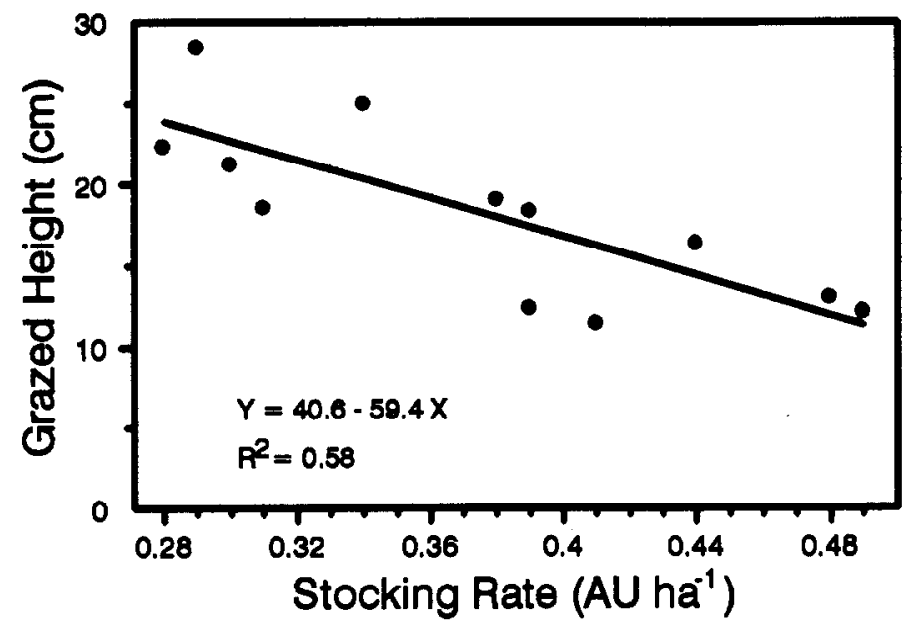

Fig. 1. Predicted grazed height of little bluestem as a function of stocking rate.

pastures in 1991. Predicted grazed height (averaged over year) for the lightest stocking rate $\left(0.28 \mathrm{AU} \mathrm{ha}^{-1}\right)$ was $23.9 \mathrm{~cm}$ and $11.4 \mathrm{~cm}$ for the heaviest stocking rate $\left(0.49 \mathrm{AU} \mathrm{ha}^{-1}\right)$. Clipping studies involving little bluestem have imposed grazed heights of 3 and $5 \mathrm{~cm}$ (Carmen and Briske 1982), $5 \mathrm{~cm}$ (Carmen 1985), $6 \mathrm{~cm}$ (Carmen and Briske 1985), $7 \mathrm{~cm}$ (Welker et al. 1987), and $15 \mathrm{~cm}$ (Smith and Leinweber 1971, Briske and Anderson 1992). Thus, our data indicate most clipping studies on little bluestem impose grazed heights which are more severe than those found under field conditions.
Number of Defoliations in a Grazing Season

Individual multiple regression prediction equations were developed for the 8 categories describing defoliation frequency (Table 1). The amount of variation explained by the regression equations was greatest when tillers remained undefoliated or were defoliated only once. As stocking rate increased for both grazing systems, the frequency of defoliation increased (Fig. 2). The percentage of tillers undefoliated during the grazing season declined from 32 to $5 \%$ in rotational system pastures and from 22 to $0 \%$ in the continuous system pastures, as stocking rate increased from 0.3 to $0.5 \mathrm{AU} \mathrm{ha}^{-1}$. Hart et al. (1993) found $19 \%$ and $36 \%$ of western wheatgrass (Agropyron smithii Rydb.) tillers and $42 \%$ and $54 \%$ of blue grama [Bouteloua gracilis (H.B.K.) Lag. ex Steud.] tillers were undefoliated throughout the grazing season under heavy ( 1 steer $2.25 \mathrm{ha}^{-1}$ ) and moderate ( 1 steer $3.0 \mathrm{ha}^{-1}$ ) stocking, respectively.

At the same stocking rate, continuous grazing systems had fewer tillers undefoliated during the grazing season (Fig. 2). Clark et al. (1984), using a forage mix of perennial ryegrass (Lolium perenne L.), browntop (Agrostis spp.), and white clover (Trifolium repens L.), observed all species were defoliated more frequently under continuous grazing than rotational grazing when rest periods exceeded 21 days. Hart et al. (1993), however, determined frequency of defoliation was similar between continuous and rotational grazing systems. Gammon and Roberts (1978a) also found small differences in frequencies of defoliation between continuous and rotational grazing systems; a small proportion of the tillers received more than 4 defoliations under continuous grazing, while no tillers were defoliated more than 3 times under rotational grazing (Gammon 1978). Hart et al. (1993) utilized lower sampling intensity, fewer defoliation event categories, and a less diverse and

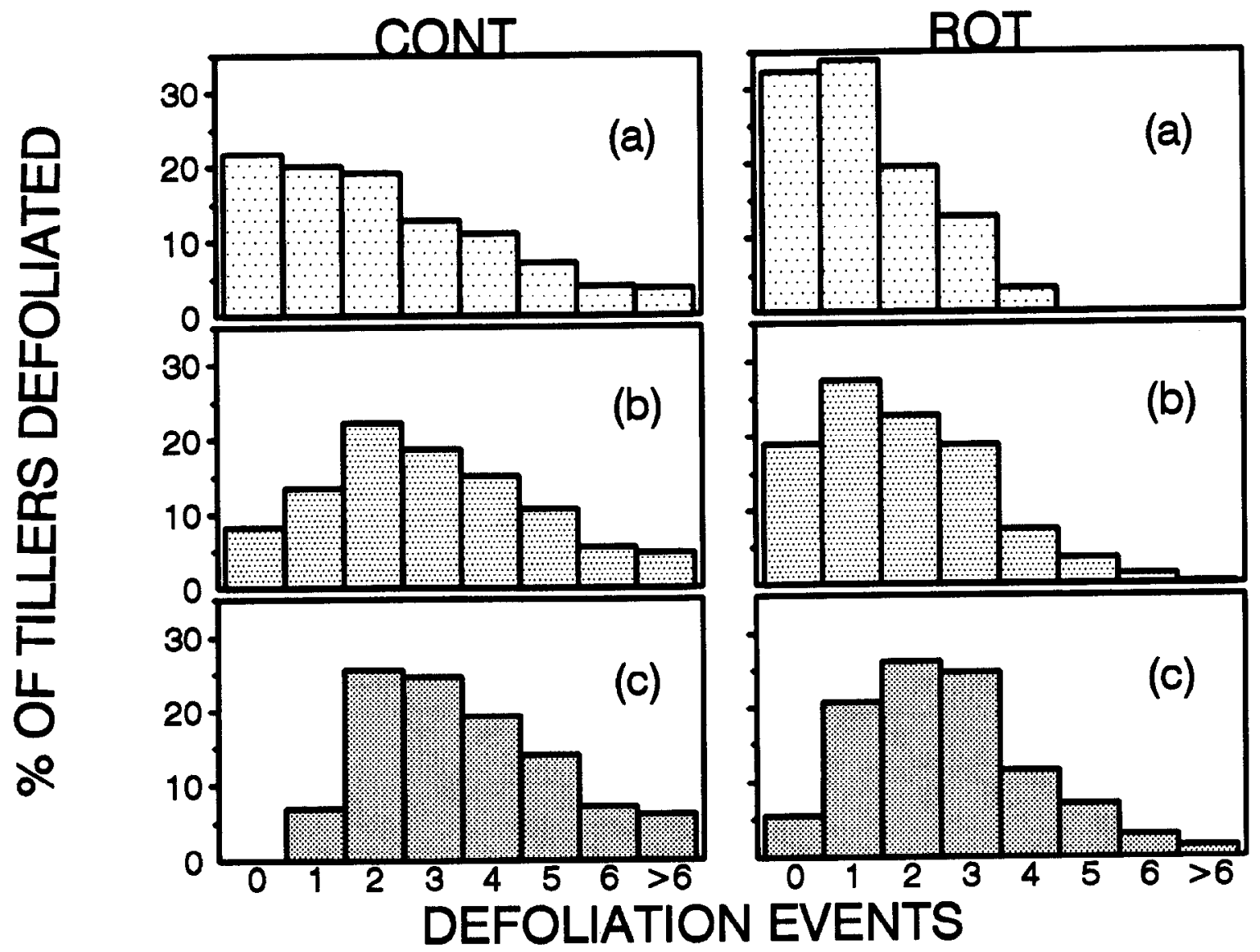

Fig. 2. Predicted number of defoliation events in a grazing season at (a) light stocking rate, $0.3 \mathrm{AU} \mathrm{ha}^{-1}$, (b) moderate stocking rate, $0.4 \mathrm{AU}$ ha $\mathrm{a}^{-1}$, and (c) heavy stocking rate, $0.5 \mathrm{AU} \mathrm{ha}^{-1}$. 
Table 2. Coefficients of multiple regression equations for continuous grazing system: 1) grazed height and 2) percent of tillers defoliated per sumpling period; $\mathrm{SR}=$ stocking rate, $\mathrm{YR}=$ year, $\mathrm{SD}=$ sample date, $\boldsymbol{R}^{2}=$ coefficient of determination. All regression coefficients significant at $P<0.05$.

\begin{tabular}{|c|c|c|c|c|c|c|c|c|}
\hline Equation & $b_{0}$ & SR & YR & $\mathrm{SD}$ & $\mathrm{SR}^{2}$ & $S R * S D$ & $\mathrm{SD}^{*} \mathrm{YR}$ & $R^{2}$ \\
\hline $\begin{array}{l}\text { Grazed height } \\
\% \text { Defoliated }\end{array}$ & $\begin{array}{r}25.1 \\
141.5\end{array}$ & $\begin{array}{l}-31.8 \\
872.4\end{array}$ & -8.5 & 2.0 & -1049.4 & -4.0 & -0.3 & $\begin{array}{l}0.46 \\
0.65\end{array}$ \\
\hline
\end{tabular}

productive plant community than our study, while Gammon and Roberts (1978a) had longer grazing periods and a longer grazing season.

\section{Within Grazing Systems Continuous Grazing}

Stocking rate, sample date, and their interaction influenced grazed heights in the continuous grazing system (Table 2). Increasing the stocking rate resulted in a decrease in grazed height. According to the prediction model, grazed height at a light stocking rate $\left(0.28 \mathrm{AU} \mathrm{ha}^{-1}\right)$ would be $17 \mathrm{~cm}$ at the beginning and $26 \mathrm{~cm}$ at the end of the grazing season; corresponding values at a heavy stocking rate $\left(0.48 \mathrm{AU} \mathrm{ha}^{-1}\right)$ would be 10 and $11 \mathrm{~cm}$. Grazed height increased as sample date progressed during the grazing season. The interaction variable modified this increase, however, as grazed height increased $0.9 \mathrm{~cm}$ per sample date at the light stocking rate and $0.1 \mathrm{~cm}$ per sample date at the heavy stocking rate.

There were $8.5 \%$ fewer tillers defoliated in 1992 than in 1991 , reflective of the increased forage production. Sample date did not influence the percentage of tillers defoliated in 1991 and resulted in a slight decrease of $0.3 \%$ tillers defoliated per sample date in 1992 (Table 2). At a given stocking rate the percentage of tillers defoliated biweekly was generally similar over the grazing season.

\section{Rotational Grazing}

Increasing stocking rates decreased both the middle and exit grazed heights of little bluestem across the grazing cycles. Gillen et al. (1990), however, reported stocking rate in rotational grazing had little effect on grazed height. Grazed heights were reduced by 1 $\mathrm{cm}$ with each advance in the grazing cycle during 1991, but increased by $2.5 \mathrm{~cm}$ with each advance during 1992. This may be attributed to the differences in growing season precipitation between 1991 and 1992. With the increased forage production in 1992 grazed heights should accordingly have been higher. Grazed heights were reduced $0.5 \mathrm{~cm}$ from the middle observation to the exit observation $(P<0.10)$, indicating more grazing pressure on little bluestem during the second half of each grazing period (Table 3).

The percentage of tillers defoliated in both the middle and exit observations across the grazing cycles was increased by increasing the stocking rate (Table 3). Heitschmidt et al. (1982) stated the pattern of tiller defoliation will change if stocking rate is increased and all other factors remain constant. An increase in stocking rate will result in defoliation of a greater number of tillers of the same species or defoliation of a greater number of plant species (Heitschmidt et al. 1982). Hart et al. (1993) found fewer undefoliated blue grama tillers and more tillers defoliated once under heavy than under moderate stocking.

Table 3. Coefficients of multiple regression equations for rotational grazing system: 1) grazed height and 2) percent of tillers defoliated per cycle; $S R=$ stocking rate, $\mathrm{YR}=$ year, $\mathrm{CY}=$ cycle, $\mathrm{OBS}=$ observation, $R^{2}=$ coefficient of determination. All regression coefficients significant at $P<0.05$.

\begin{tabular}{|c|c|c|c|c|c|c|c|c|c|c|c|}
\hline Equation & $\mathbf{b}_{0}$ & SR & YR & CY & OBS & $S R * Y R$ & $\mathrm{CY}^{*} \mathrm{YR}$ & $\mathrm{OBS}^{*} \mathbf{Y R}$ & $S^{2}{ }^{2}$ OBS & $\begin{array}{c}\mathrm{SR}^{2} \\
\mathrm{YR} \mathrm{R}^{*} \mathrm{OBS}\end{array}$ & $R^{2}$ \\
\hline $\begin{array}{l}\text { Grazed height } \\
\% \text { Defoliated }\end{array}$ & $\begin{array}{r}48.5 \\
-14.9\end{array}$ & $\begin{array}{c}-63.0^{1} \\
71.5\end{array}$ & $\begin{array}{l}-12.5 \\
-12.3\end{array}$ & $\begin{array}{r}-1.0 \\
3.5\end{array}$ & $\begin{array}{c}-0.5^{1} \\
6.1\end{array}$ & 30.5 & 3.5 & -5.3 & -1.2 & 23.3 & $\begin{array}{l}0.63 \\
0.72\end{array}$ \\
\hline
\end{tabular}

ISignificant at $P<0.10$.
There were $12 \%$ fewer tillers defoliated in 1992 , reflective of increased forage production. With each advance in grazing cycle, $3.5 \%$ more tillers were defoliated. This was to be expected due to the lengthening of the grazing period over the grazing season.

Six percent more tillers were defoliated in the exit observations compared with middle observations in 1991. At light stocking rates in 1992 differences in percent of tillers defoliated between the middle and exit observations were small; larger differences were found at heavy stocking rates in 1992 . This indicated more grazing pressure on little bluestem during the second half of each grazing period. Walker et al. (1989) also found cattle were more selective at the beginning of a rotational grazing period than at the end.

Prediction equations were developed for number of defoliations within a grazing cycle using individual models for defoliation categories none, once, and twice (Table 4). The percentage of undefoliated tillers decreased and the percentage of tillers defoliated once and twice increased with increasing stocking rate (averaged over cycles, Fig. 3). Less than $10 \%$ of the tillers were regrazed

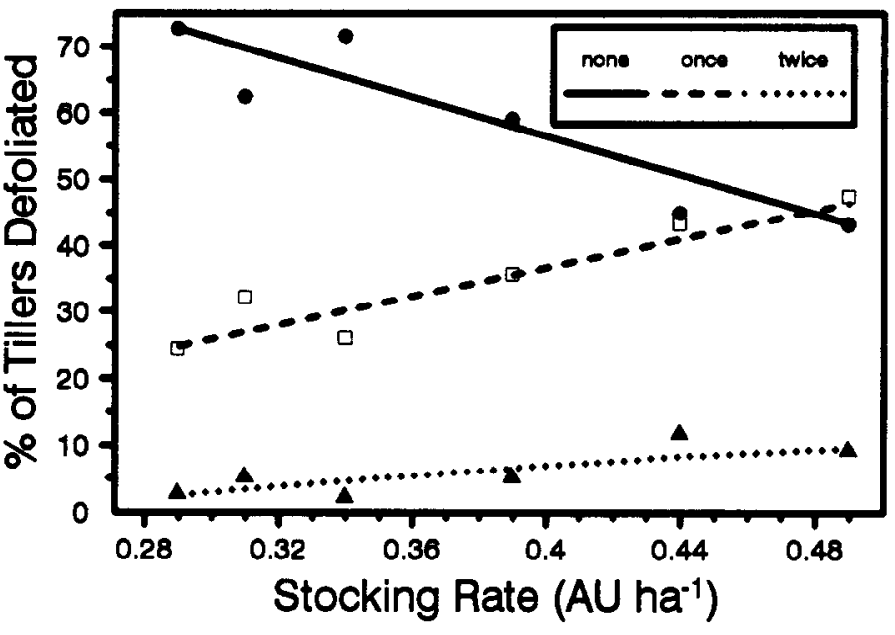

Fig. 3. Predicted effect of stocking rate on number of defoliation events within a rotational grazing cycle.

within a cycle, even with heavy stocking rates. Although the stocking rate $X$ year interaction variable was significant (Table 4), trends between years for each of the 3 defoliation categories were similar. Hart and Balla (1982) found tillers of western wheatgrass and crested wheatgrass [Agropyron desertorum (Fisch. ex Link) Schult.] were defoliated more frequently under higher stocking rates. Hart et al. (1993) determined defoliation frequency of western wheatgrass and blue grama tillers increased with increased stocking rate. 
Table 4. Coefficients of multiple regression equations for number of defoliation events in a rotational grazing cycle, $D . E .=$ defoliation events, $\mathbf{S R}=$ stocking rate, $Y R=$ year, $R^{2}=$ coeffieient of determination. All regression coefficients significant at $P<0.05$.

\begin{tabular}{lcccccccc}
\hline \hline D.E. & b & Cycle & SR & YR & SR*Cycle & SR*YR & SR ${ }^{* *}$ YR $^{*}$ & $R^{2}$ \\
\hline 0 & 116.5 & -5.5 & -116.7 & 25.0 & & -59.4 & & 0.77 \\
1 & -7.5 & 4.1 & 85.2 & -18.6 & & 45.5 & 0.78 & \\
2 & 2.9 & -2.5 & -0.31 & -22.5 & 10.6 & 94.4 & -96.8 & 0.60 \\
\hline
\end{tabular}

iSignificant at $P<0.10$.

As the grazing cycles progressed, the percentage of tillers undefoliated decreased and the percentage of tillers defoliated once and twice increased (averaged over stocking rates, Fig. 4). In Texas, Briske and Stuth (1982) found a large percentage of brownseed paspalum ( Paspalum plicatulum Michx.) tillers were undefoliated or were only lightly defoliated even at relatively high stock densities with an 11-day grazing period. Gammon and Roberts (1980) found less than $60 \%$ of the tillers from the most selected species

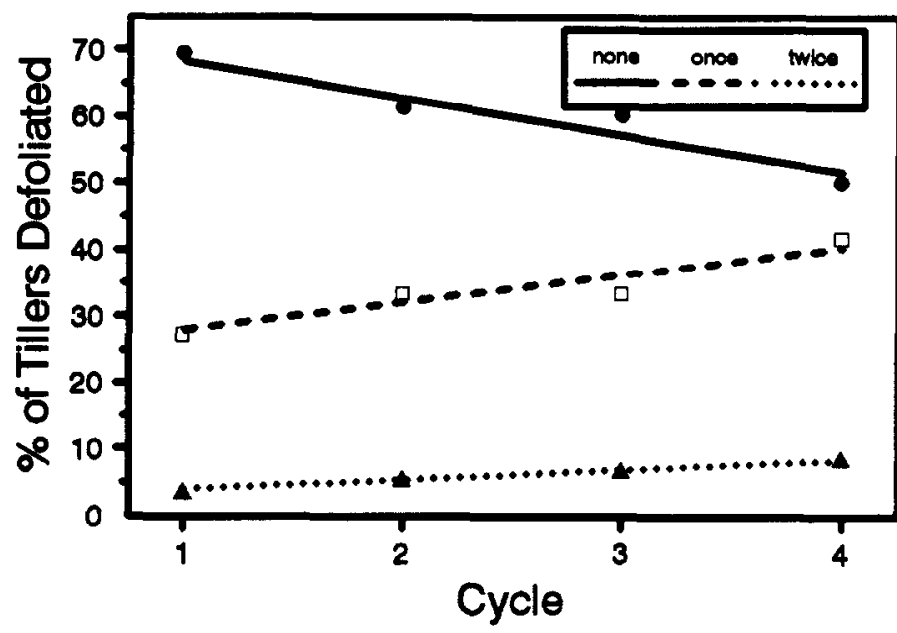

Fig. 4. Predicted effect of grazing cycle on number of defoliation events within a rotational grazing cycle.

were defoliated in a single grazing period under rotational grazing. Again, we found regrazing of an individual tiller was minimal within a grazing cycle even as the grazing period lengthened.

\section{Conclusions}

Stocking rate was the predominant variable influencing grazed height, percentage of tillers defoliated, and number of defoliations within a grazing cycle. In the rotational system, regrazing of individual tillers within a grazing cycle was less than $10 \%$ even under the heaviest stocking rate and longest grazing period. This result confirms that rotational grazing allows greater control of defoliation frequency as previously assumed (Denny and Barnes 1977, Hinnant and Kothmann 1986). Rotational grazing, however, does not afford greater control over defoliation intensity as evidenced by the occurrence of similar grazed heights within continuous and rotational grazing systems. Heitschmidt et al. (1990) also determined the relative intensity of defoliation did not vary among species or grazing periods in a mixed-grass prairie grazed on a rotational basis indicating that intensity of defoliation was primarily a function of pre-defoliation height.

Grazed heights were similar between the 2 systems and were influenced primarily by stocking rate. Based on these data, we hypothesize that increased standing crop under rotational grazing (unpublished data, Gillen et al.) may be attributed to reduced forage intake by livestock (Denny et al. 1977) and less regrazing of individual tillers, especially at light stocking rates. This reduction in livestock intake may be the primary reason rotational grazing systems do not maximize animal performance. Investigations of forage intake by livestock (unpublished data, McCollum et al.) and animal performance (unpublished data Gillen et al.) on the study area support this hypothesis.

Fewer tillers remain undefoliated during a grazing season in continuous grazing systems compared to rotational grazing systems at similar stocking rates; correspondingly, the frequency distribution of defoliated tillers shifts to higher defoliation classes in continuous grazing systems. Little bluestem plants should not receive multiple defoliations in consecutive years unless the purpose is to weaken large plants so that remaining tillers at the periphery will form new, smaller plants (Mullahey et al. 1990). Fragmentation of individual large plants results in greater plant density but smaller basal areas per individual plant (Butler and Briske 1988).

Continuous and rotational grazing systems differ little in terms of their effects on range condition in the short-term (Denny et al. 1977, Pitts and Bryant 1987, Hart et al. 1988, O'Reagain and Turner 1992). However, we hypothesize higher range condition will be maintained over the long-term in rotational system pastures. As a result of fewer defoliation events throughout the grazing season, little bluestem plants in the rotational system pastures would remain more competitive and productive than those in the continuous system pastures. Thus, little bluestem plants in rotational system pastures would be more effective competitors for available water and nutrient resources. Conversely, little bluestem plants in continuous system pastures which have been exposed to more defoliation events throughout the grazing season will be subjected to more intense competition for available water and nutrient resources. Over an extended period of time, little bluestem plants in continuous grazed pastures may be replaced by more resource competitive and defoliation-tolerant species which are of a lower seral state.

\section{Literature Cited}

Briske, D.D., and J.W. Stuth. 1982. Tiller defoliation in a moderate and heavy grazing regime. J. Range Manage. 35:511-514.

Briske, D.D., and V.J. Anderson. 1992. Competitive ability of the bunchgrass Schizachyrium scoparium as affected by grazing history and defoliation. Vegetatio 103:41-49.

Brown, J.R., and J.W. Stuth. 1984. The probability of individual tillers being grazed in a short-duration grazing system. p. 197-203. In: Proc. Forage Grassl. Conf., Houston, Tex., Amer. Forage and Grassl. Counc.

Butler, J.L., and D.D. Briske. 1988. Population structure and tiller demography of the bunchgrass Schizachyrium scoparium in response to herbivory. Oikos 51:306-312.

Carmen, J.G. 1985. Morphological characterization and defoliation responses of selected Schizachyrium scoparium genotypes. Amer. Midl. Natur. 114:37-43.

Carmen, J.G., and D.D. Briske. 1982. Root initiation and root and leaf elongation of dependent little bluestem tillers following defoliation. Agron. J. 74:432-435.

Carmen, J.G., and D.D. Briske. 1985. Morphologic and allozymic variation between long-term grazed and non-grazed populations of the bunchgrass Schizachyrium scoparium var. frequens. Oecologia 66:332-337. 
Clark, D.A., D.F. Chapman, C.A. Land, and N. Dymock. 1984. Defoliation of Lolium perenne and Agrostis spp. tillers, and Trifolium repens stolons in set-stocked and rotationally grazed hill pastures. New Zealand J. Agr. Res. 27:289-301.

Denny, R.P., and D.L. Barnes. 1977. Trials of multi-paddock grazing systems on veld 3 . A comparison of six grazing procedures at 2 stocking rates. Rhod. J. Agric. Res. 15:129-142.

Denny, R.P., D.L. Barnes, and T.C.D. Kennan. 1977. Trials of multipaddock grazing systems on veld. 1. An exploratory trial of systems involving twelve paddocks and one herd. Rhod. J. Agr. Res. 15:11-23.

Gammon, D.M. 1978. Patterns of defoliation during continuous and rotational grazing of rangeland by cattle. In: D.N. Hyder (ed.), Proc. 1st Int. Rangeland Congr. Soc. Range Manage., Denver, Colo.

Gammon, D.M. and B.R. Roberts. 1978a. Patterns of defoliation during continuous and rotational grazing of the Matopos Sandveld of Rhodesia. I. Selectivity of grazing. Rhod. J. Agr. Res. 16:117-131.

Gammon, D.M., and B.R. Roberts. 1978b. Patterns of defoliation during continuous and rotational grazing of the Matopos Sandveld of Rhodesia. 2. Severity of defoliation. Rhod. J. Agr. Res. 16:133-145.

Gammon, D.M., and B.R. Roberts. 1978c. Patterns of defoliation during continuous and rotational grazing of the Matopos Sandveld of Rhodesia. 3. Frequency of defoliation. Rhod. J. Agr. Res. 16:147-164.

Gammon, D.M., and B.R. Roberts. 1980. Aspects of defoliation during short duration grazing of the Matopos Sandveld of Zimbabwe. Zimbabwe J. Agr. Res. 18:29-38.

Gillen, R.L., F.T. McCollum, and J.E. Brummer. 1990. Tiller defoliation patterns under short duration grazing in tallgrass prairie. J. Range Manage. 43:95-99.

Hart, R.H., and E.F. Balla. 1982. Forage production and removal from western and crested wheatgrasses under grazing. J. Range Manage. 35:362-366.

Hart, R.H., M.J. Samuel, P.S. Test, and M.A. Smith. 1988. Cattle, vegetation, and economic responses to grazing systems and grazing pressure. $J$. Range Manage. 41:282-286.
Hart, R.H., S. Clapp, and P.S. Test. 1993. Grazing strategies, stocking rates, and frequency and intensity of grazing on western wheatgrass and blue grama. J. Range Manage. 46:122-126.

Heitschmidt, R.K., D.D. Briske, and D.L. Price. 1990. Pattern of interspecific tiller defoliation in a mixed-grass prairie grazed by cattle. Grass and Forage Sci. 45:215-222.

Heitschmidt, R.K., J.R. Frasure, D.L. Price, and L.R. Rittenhouse. 1982. Short duration grazing at the Texas Experimental Ranch: weight gains of growing heifers. J. Range Manage. 35:375-379.

Hinnant, R.T., and M.M. Kothmann. 1986. Frequency and intensity of defoliation under rotational grazing. Texas Agr. Exp. Sta. Prog. Rep. 4424.

Kothmann, M.M. 1980. Evaluation of livestock needs in designing grazing systems for rangeland. In: D.C. Church (ed.), Digestive Physiology and Nutrition of Ruminants. Vol. 3. Practical Nutrition. 2nd ed. O \& B Books, Corvallis, Ore. pp. 56-90.

Mullahey, J.J., S.S. Waller, and L.E. Moser. 1990. Defoliation effects on production and morphological development of little bluestem. J. Range Manage. 43:497-500.

Myers, H.R. 1982. Climatological data of Stillwater, Oklahoma 1893-1980. Oklahoma Agr. Exp. Sta. Res. Rep. 821.

O'Reagain, P.J. and J.R. Turner. 1992. An evaluation of the empirical basis for grazing management recommendations for rangeland in southern Africa. J. Grass. Soc. South. Africa. 9:38-49.

Pitts, J.S., and F.C. Bryant. 1987. Steer and vegetation response to short duration and continuous grazing. J. Range Manage. 40:386-389.

Smith, A.E., and C.L. Leinweber. 1971. Relationship of carbohydrate trend and morphological development of little bluestem tillers. Ecology 52:1052-1057.

Walker, J.W., R.K. Heitschmidt, and S.L. Dowhower. 1989. Some effects of a rotational grazing treatment on cattle preference for plant communities. J. Range Manage. 42:143-148.

Welker, J.M., D.D. Briske, and R.W. Weaver. 1987. Nitrogen-15 partitioning within a three generation tiller sequence of the bunchgrass Schizachyrium scoparium: response to selective defoliation. Oecologia 74:330-334. 